\title{
Misoprostol use in obstetrics
}

\section{O uso do Misoprostol em Obstetrícia}

\author{
1 Fabíola Augusta Marinho Chaves fabima1108@gmail.com \\ 1 Julio Cesar Soares Aragão
}

1 Centro Universitário de Volta Redonda - UniFOA.

\begin{abstract}
Introduction: Misoprostol is a prostaglandin E1 analogue, has an anti-secretory action and mucosal protective properties, as well as increasing uterine contractility, inducing the development of contractions and causing erection of the cervix. Method: The present research constitutes a narrative review on misoprostol and its use in obstetrics, aiming at an overview of the use, indications and contraindications in obstetrics and reviewing a total of 33 academic articles in Portuguese, Spanish and English published from 2005 to 2014. Results: Misoprostol induces the contractility of the myometrial fiber, facilitating the dilation necessary to perform obstetric procedures. It is an important medicine in obstetrical practice, and is indicated for the treatment of abortion, labor induction, in situations where the cervix does not show dilatation, it can shorten surgery time, reduce the frequency of complications and indications of cesarean section, besides being used in the prophylaxis of postpartum haemorrhage. Attention should be paid to its misuse as an abortive and the existence of reports of cases of congenital malformations, mainly Moebius Syndrome. Conclusion: Misoprostol is a stable, safe, effective, inexpensive, and easy-to-administer drug that ensures the broad employability of its clinical use in current obstetrics.
\end{abstract}

\section{Keywords:}

Misoprostol. Abortion. Delivery .

\section{Resumo}

Introdução: O misoprostol é um análogo da prostaglandina E1, tem ação antissecretora e propriedades protetoras de mucosa, além de provocar o aumento da contratilidade uterina, induzir o desenvolvimento de contrações e causar o apagamento do colo do útero. Método: O presente trabalho constitui uma revisão narrativa sobre o misoprostol e seu uso na obstetrícia, com objetivo de ter uma visão geral sobre o uso, indicações e contraindicações na obstetrícia e revendo um total de 33 artigos acadêmicos nas línguas portuguesa, espanhola, e inglesa no intervalo de 2005 a 2014. Resultados: O misoprostol possui uma atividade indutora da contratilidade da fibra miometrial, facilitando a dilatação necessária à realização de procedimentos obstétricos. É um medicamento importante na prática obstétrica, sendo indicado para tratamento de aborto retido, indução de trabalho de parto, em situações em que o colo uterino não apresenta dilatação, pode encurtar o tempo de operação, reduzir a frequência de complicações e de indicações de cesariana, além de ser usado na profilaxia da hemorragia pós-parto. Deve-se atentar para seu uso indevido como abortivo e a existência de relatos de casos de malformações congênitas, principalmente a Síndrome de Moebius. Conclusão: o misoprostol é um medicamento estável, seguro, eficaz, barato e de fácil administração, que Ihe garantem ampla empregabilidade do seu uso clínico na obstetrícia atual.

\section{Palavras-chave:}

Misoprostol. Aborto. Parto.

\section{Como você deve citar?}

CHAVES, Fabíola Augusta Marinho; ARAGÃO, Julio Cesar Soares. Misoprostol use in obstetrics. Cadernos UniFOA, Volta Redonda, n. 38, p. 121-127, dez. 2018. 


\section{INTRODUCTION}

Misoprostol was originally developed in the 1970s for gastritis and peptic ulcer prevention. It is a synthetic analogue of prostaglandin E1 and has anti-secretory action and mucosa protective properties (SILVERSTEIN, 1998). In 1985 it was approved by the Health Surveillance Secretariat of Brazilian Ministry of Health (VILLELA; MASTRELLA, 2012).

At the same time, it was observed that its use in pregnancy would cause an increase in myometrial contractile activity, inducing contractions, cervix effacement and facilitating the dilation necessary to perform obstetric procedures (COÊLHO, 1998). The first internationally published study on the use of misoprostol for labor induction in fetal demise was performed by Mariani Neto et al. (1987), in São Paulo, using $400 \mu \mathrm{g}$ of misoprostol every four hours. On the other hand, the first study published on misoprostol as a maturation agent and inducer of labor in pregnant women with a live fetus was performed in Argentina (Margulies et al.,1991 apud (ERAZO; LIZCANO, 2013). From 1998, 25mcg misoprostol tablets for vaginal use, exclusively indicated for labor induction and restricted hospital use were launched in Brazil. Due to its use as an abortifacient, misoprostol use in Brazil is restricted to hospitals. (OPALEYE et al., 2010; OSORIO-DE-CASTRO et al., 2004; RANGEL FILHO et al., 2007).

Studies have shown greater efficacy and less side effects using vaginal misoprostol. Differences in pharmacokinetics of the oral use with vaginal administration show a more favorable profile for the later, resulting in a longer effect duration, more stable plasma levels and larger area under the curve. In addition, the systemic bioavailability with vaginal administration is three times higher than that observed with oral use, providing smaller doses and longer intervals (FEITOSA et al., 2006).

The choice of misoprostol as a method for pregnancy termination should be shared between health professionals and women, respecting conscientious and informed decision-making. Patients should be advised of misoprostol side effects, especially with regard to pain, and of the available alternatives to control and reduce these effects (ERAZO; LIZCANO, 2013; VILLELA; MASTRELLA, 2012).

The objective of this study is to perform a comprehensive review on the use of misoprostol in obstetrics in Brazil, regarding its use, indications, contraindications and clinical results.

\section{METHOD}

For this study, a comprehensive literature review was used based on the collection of data in scientific articles, which were analyzed in relation to the proposed theme. This review included articles in the Portuguese, English and Spanish languages between 2005 and 2014, in addition to some classic articles, using the following databases: Pubmed, Scielo, Google Scholar and LILACS. The key words used were misoprostol, abortion and parturition. All results referring to non-human use of misoprostol were excluded of this study.

The search retrieved 33 articles ( 14 from Scielo, 7 from Google Scholar, 6 from Pubmed and 6 from LILACS), that were grouped as: 16 for indications, 10 for results and 7 for complications. The results were tabulated, classified and submitted to critical analysis in order to constitute a narrative review (CORDEIRO et al., 2007). 


\section{$3 \quad$ RESULTS AND DISCUSSION}

\subsection{Pharmacokinetics and Mechanism of Action}

Misoprostol is rapidly absorbed following oral administration and is metabolized in the liver resulting in a metabolically active free misoprostol acid. It has half-life of approximately 0.3 hours reaching plasma level in 60-90 minutes, its effect can last up to 3 hours and is subsequently excreted approximately $80 \%$ by urine and $15 \%$ by feces (SILVA; RAMOS; PARTATA, 2013). Misoprostol acts directly on parietal cell, inhibiting the basal secretion of gastric acid, increasing mucosa blood flow and also stimulating mucus and bicarbonate secretion (RANG et al., 2008). In the uterine cervix, the increase of prostaglandin produces collagen fibers dissolution, increases hyaluronic acid and water content of its extracellular matrix. In addition to causing cervix smooth muscle relaxation and dilation, it allows increase of intracellular calcium, promoting uterine contraction (SOUZA et al., 2010).

\subsection{Missed Abortion}

Single dose vaginal misoprostol $800 \mu \mathrm{g}$ is a safe and effective alternative to uterine curettage for interrupted first trimester gestation (ARCANJO et al., 2011). The vaginal administration of misoprostol in a single $800 \mu \mathrm{g}$ daily dose in a $48 \mathrm{~h}$ course in spontaneous abortion also presents better results in young, primipara patients, without previous curettage and abortion or vaginal bleeding greater or equal to menstruation (CAMACHO et al., 2012). A study by Mayi-Tsonga (2014) demonstrated that sublingual $400 \mathrm{\mu g}$ misoprostol is effective in completing incomplete abortion. This study found an efficacy of $95.5 \%$, and an average of 35 minutes for initiation of contractions, concluding that misoprostol is a safe and acceptable method for the treatment of incomplete first trimester abortions (ADISSO et al., 2014).

Misoprostol has recently been added to the WHO list of essential medicines for incomplete abortion cases. The recommended regimen is a single dose of $600 \mathrm{mcg}$ oral misoprostol in the range of 1 to 2 weeks for women with a uterine size equivalent to 12 weeks or less (BLUM et al., 2007).

It is also indicated in fetal demise cases at any gestational age, whenever there is no contraindication to vaginal delivery or misoprostol use. In this case the vaginal application of the drug is preferable to avoid systemic adverse effects. It should be noted that the uterus sensitivity to misoprostol increases with gestational age and the more advanced the pregnancy, the lower the dose that should be used. For induction in the 2nd trimester the recommended dose is 400 mcg every 4 hours until the fetus is eliminated (ERAZO; LIZCANO, 2013).

As a result of increased uterine prostaglandin sensitivity with pregnancy advance, the recommended doses vary according to gestation period. From 13 to 17 weeks, 200 mcg of vaginal misoprostol every 6 hours, $100 \mathrm{mcg}$ of vaginal misoprostol every 6 hours are recommended for 18-26 weeks and 25-50 mcg every 4 hours are used for a gestational age of more than 27 weeks. If the first dose fails to produce effective contractions, the second dose may be duplicated. Due to uterine rupture risk, it is recommended that women with uterine scars should receive lower doses and not be submitted to an increase in dose if there is no initial response (LEÓN; WING; FIALA, 2007).

\subsection{Labor induction}

Several studies have shown that misoprostol decreases induction and labor time, c-section rates, postpartum haemorrhage. As prolonged latent phase occurs mainly due to cervix immaturity, misoprostol is indicated as a therapeutic agent based on etiological treatment. It is also defined as an non-invasive treatment (NICHOLSON et al., 2009; RANGEL FILHO et al., 2007). 
The currently recommended dose by the Brazilian Ministry of Health and the American College of Obstetricians and Gynecologists is $25 \mu \mathrm{g}$ every three to six hours, given vaginally. However, one study showed that a $12.5 \mu \mathrm{g}$ vaginal dose of misoprostol, applied every four hours, is efficient and safe for labor induction, with low rates of cesarean section and tachysystole, few maternal side effects and good perinatal outcomes (RANGEL FILHO et al., 2007).

There is little doubt of results when comparing low-dose oral and vaginal misoprostol regimens in labor induction, but one study has shown that the $20 \mathrm{mcg}$ oral misoprostol dose regimen administered every 2 hours for up to 12 doses is as effective as vaginal misoprostol in performing vaginal delivery, though with a much lower rate of uterine hyperstimulation. The recommended doses for induction of labor with misoprostol are after that a $25 \mathrm{mcg}$ vaginally or $50 \mathrm{mcg}$ orally every 4 hours for a maximum of six doses (ELATI; WEEKS, 2009).

Compared to Foley catheter use, misoprostol presented shorter cervical preparation time, spontaneous onset of labor and tendency to lower cesarean rate (OLIVEIRA et al., 2010).

Misoprostol is not contraindicated in patients in the presence of uterine scarring, but there is no certainty about the optimal dosage and there is no consensus on the action to be taken in the absence of expulsion. For safety measures, it is recommended the use of half of the usual dose of misoprostol to minimize risk of uterine rupture (MACEDO; ÁVILA; GONÇALVES, 1998; OUERDIANE et al., 2015; RANGEL FILHO et al., 2007).

\subsection{Cervical dilation}

Both oral and vaginal use for cervical dilatation have been shown to be efficient prior to vacuum aspiration in pregnant women. The $400 \mathrm{mcg}$ dose of misoprostol given 3 hours prior to the procedures is recommended as an optimal dose. The oral or sublingual route is equally effective and has the advantage of being more convenient and more acceptable to women. A single dose of $400 \mathrm{mcg}$ vaginal or sublingual 3 hours prior to transcervical procedures has been recommended (ELATI; WEEKS, 2009).

\subsection{Postpartum haemorrhage}

Misoprostol was also evaluated as a prophylactic method for postpartum haemorrhage. In a randomized trial, DERMAN et al. (2006) compared a $600 \mathrm{mg}$ dose of misoprostol with placebo given at delivery. Puerperal bleeding was significantly reduced (from 12 to $6 \%$ ), and severe bleeding decreased from 1.2 to $0.2 \%$ with misoprostol. However, SOUSA (2010) states that misoprostol labor induction does not alter blood loss during labor, either in induced vaginal deliveries or in cesareans with a previous induction attempt. The preoperative use of $400 \mu \mathrm{g}$ of sublingual misoprostol during anesthesia with isoflurane for cesarean section was associated with a significant $71.6 \%$ reduction in perioperative blood loss. This reduction inhibited the relaxation of the isoflurane-induced uterine smooth muscle and showed higher levels of hematocrit, comparative neonatal outcome and a higher incidence of tremors (EL TAHAN et al., 2012; KHAN et al., 2006).

WHO currently recommends oxytocin use instead of misoprostol for the postpartum haemorrhage prevention. However, in places where there is no availability of injectable uterotonics or where there are problems with their storage and administration, misoprostol is indicated as part of the active management of the third period for the prevention of postpartum haemorrhage. The recommended dosage is a single dose of $600 \mathrm{mcg}$ of oral or sublingual misoprostol and repeated dosing is not recommended for 2 hours (ELATI; WEEKS, 2009). 


\subsection{Congenital malformations}

Among the most frequently reported malformations caused by this drug, the main one is Moebius syndrome (CHEYNE et al., 2014). This is a rare clinical condition characterized by paralysis of cranial nerves with unilateral or bilateral ocular or facial involvement, often associated with paralysis of other cranial nerves and manifested by anomalies of orofacial structures, such as face mask, convergent strabismus, paralysis and hypoplasia of the tongue defects, such as unilateral or bilateral equinocarp, syndactyly, brachydactyly (OPALEYE et al., 2010). In a study carried out in Argentina, Barbero et al. (2011) have detected a significant increase in the risk of birth defects in children exposed to misoprostol. The mean dose used was $1439 \mathrm{mcg}$ and even cases in which the fetuses were not exposed to higher doses than the means presented typical defects of embryopathy. In the majority of cases, the exposure occurred between the 5th and 12th weeks of gestation, and no malformations were observed in exposed fetuses after the 13th week. Other studies have demonstrated transverse limb defects association with Moebius syndrome (MENGUE; PIZZOL, 2008; PIZZOL; KNOP; MENGUE, 2006).

\section{CONCLUSION}

Misoprostol causes relaxation of the smooth muscle of the uterine cervix and favors dilatation, promoting effective and smooth uterine contraction. Its use in Brazil is restricted to the hospitals because of unlawful risk of its use as abortifacient.

It is indicated for the resolution of fetal demise cases, with retained fetus up to 12 weeks, due to the risk of complications and the need for manual intrauterine aspiration to complete evacuation. In addition to being preferentially used for labor induction in situations where cervix presents without any dilatation and effacement, caution is recommended for patients with uterine scars, due to uterine rupture risk. Misoprostol may facilitate mechanical dilation, shorten operation time, reduce blood loss, and decrease the complications frequency in these cases. In patients who use it with the intention of interrupting gestation, congenital malformations may occur, especially Moebius Syndrome.

Due to the fact that it is a stable, safe, effective, inexpensive and easy to administer drug, it is possible to conclude the wide employability of misoprostol and the importance of its contemporary clinical use in Brazil and worldwide.

\section{REFERENCES}

ADISSO, S. et al. Introduction of misoprostol for the treatment of incomplete abortion beyond 12 weeks of pregnancy in Benin. International Journal of Gynecology \& Obstetrics, v. 126, p. S36-S39, jul. 2014.

ARCANJO, F. C. N. et al. Uso do misoprostol em substituição à curetagem uterina em gestações interrompidas precocemente. Revista Brasileira de Ginecologia e Obstetrícia, v. 33, n. 6, p. 276-280, jun. 2011.

BARBERO, D. P. et al. Efecto teratogénico del misoprostol: un estudio prospectivo en Argentina. Archivos Argentinos de Pediatria, v. 109, n. 3, p. 6, 2011.

BLUM, J. et al. Treatment of incomplete abortion and miscarriage with misoprostol. International Journal of Gynecology \& Obstetrics, v. 99, p. S186-S189, dez. 2007. 
$\mathrm{CAMACHO}$, M. et al. Factores clínicos y demográficos predictores de éxito del misoprostol en el tratamiento médico del aborto espontáneo. Revista chilena de obstetricia y ginecología, v. 77, n. 2, p. 116-121, 2012.

CHEYNE, J. R. et al. Asociación VACTERL y síndrome de Moebius en un recién nacido expuesto prenatalmente a misoprostol. latreia, v. 27, n. 2, p. 216-220, 27 mar. 2014.

COÊLHO, H. L. L. Misoprostol: a solução não é tão simples. Revista de Saúde Pública, v. 32, n. 4, p. 394-395, ago. 1998.

CORDEIRO, A. M. et al. Revisão sistemática: uma revisão narrativa. 2007.

DERMAN, R. J. et al. Oral misoprostol in preventing postpartum haemorrhage in resource-poor communities: a randomised controlled trial. Lancet (London, England), v. 368, n. 9543, p. 1248-1253, 7 out. 2006.

EL TAHAN, M. R. et al. Efeitos de misoprostol sublingual pré-operatório no tônus uterino durante anestesia com isoflurano para cesariana. Revista Brasileira de Anestesiologia, v. 62, n. 5, p. 630-635, out. 2012.

ELATI, A.; WEEKS, A. D. The use of misoprostol in obstetrics and gynaecology. BJOG: an international journal of obstetrics and gynaecology, v. 116 Suppl 1, p. 61-69, out. 2009.

ERAZO, H. O. C.; LIZCANO, E. I. O. Uso de misoprostol en obstetricia y ginecología. 3. ed. Panamá: Federación Latinoamericana de Sociedades de Obstetricia y Ginecología, 2013. v. 1

FEITOSA, F. E. DE L. et al. Nova formulação de misoprostol sublingual na indução do trabalho de parto. Revista da Associação Médica Brasileira, v. 52, 2006.

KHAN, K. S. et al. WHO analysis of causes of maternal death: a systematic review. Lancet (London, England), v. 367, n. 9516, p. 1066-1074, 1 abr. 2006.

LEÓN, R. G. P. DE; WING, D.; FIALA, C. Misoprostol for intrauterine fetal death. International Journal of Gynecology \& Obstetrics, v. 99, p. S190-S193, dez. 2007.

MACEDO, R. M.; ÁVILA, I. DE; GONÇALVES, M. M. Estudo comparativo entre misoprostol e placebo para o amadurecimento cervical e indução do parto. Revista Brasileira de Ginecologia e Obstetrícia, v. 20, n. 8, p. 457-462, set. 1998.

MARIANI NETO, C. et al. Uso do misoprostol para indução do parto com feto morto. Rev Paul Med, p. 325-328, 1987.

MAYI-TSONGA, S. et al. Première expérience de l'utilisation du Misoprostol comme soin après avortement (SAA) à Libreville, Gabon. Pan African Medical Journal, v. 18, n. 301, 142014.

MENGUE, S. S.; PIZZOL, T. DA S. D. Misoprostol, aborto e malformações congênitas. Revista Brasileira de Ginecologia e Obstetrícia, v. 30, 2008.

NICHOLSON, J. M. et al. The Association between Increased Use of Labor Induction and Reduced Rate of Cesarean Delivery. Journal of Women's Health, v. 18, n. 11, p. 1747-1758, nov. 2009. 
OLIVEIRA, M. V. DE O. E et al. Sonda de Foley cervical versus misoprostol vaginal para o preparo cervical e indução do parto: um ensaio clínico randomizado. Revista Brasileira de Ginecologia e Obstetrícia, v. 32, n. 7, p. 346-351, jul. 2010.

OPALEYE, E. S. et al. Avaliação de riscos teratogênicos em gestações expostas ao misoprostol. Revista Brasileira de Ginecologia e Obstetrícia, v. 32, n. 1, p. 19-35, jan. 2010.

OSORIO-DE-CASTRO, C. G. S. et al. Uso indicado e uso referido de medicamentos durante a gravidez. Cadernos de Saúde Pública, v. 20, n. suppl 1, p. S73-S82, 2004.

OUERDIANE, N. et al. Efficacy of misoprostol for medical termination of pregnancy in second trimester : Prospective study. La Tunisie Medicale, v. 93, n. 4, p. 212-216, abr. 2015.

PIZZOL, T. DA S. D.; KNOP, F. P.; MENGUE, S. S. Prenatal exposure to misoprostol and congenital anomalies: systematic review and meta-analysis. Reproductive Toxicology (Elmsford, N.Y.), v. 22, n. 4, p. 666-671, nov. 2006.

RANG, H. P. et al. Farmacologia. Rio de Janeiro: Elsevier, 2008.

RANGEL FILHO, F. A. et al. Baixas doses de misoprostol vaginal (12,5 versus $25 \mathrm{mcg}$ ) para indução do parto a termo. Revista Brasileira de Ginecologia e Obstetrícia, v. 29, n. 12, p. 639-646, dez. 2007.

SILVA, F. P. R.; RAMOS, M. S.; PARTATA, A. K. MISOPROSTOL: PROPRIEDADES GERAIS E USO CLÍNICO. Revista Científica do ITPAC, v. 6, n. 4, p. 10, 2013.

SILVERSTEIN, F. E. Improving the Gastrointestinal Safety of NSAIDs The Development of Misoprostol-From Hypothesis to Clinical Practice. Digestive Diseases and Sciences, v. 43, n. 3, p. 447-458, 1 mar. 1998.

SOUSA, P. C. P. DE; FEITOSA, F. E. DE L. Avaliação da perda sanguínea em gestantes submetidas à indução do parto com misoprostol. Revista Brasileira de Ginecologia e Obstetrícia, v. 32, n. 8, p. 412-412, ago. 2010.

SOUZA, A. S. R. et al. O uso do misoprostol para indução do trabalho de parto. Femina, v. 38, n. 3, p. 8, 2010.

VILLELA, M. C. D.; MASTRELLA, M. Aborto e misoprostol: usos médicos, práticas de saúde e controvérsia científica. p. 8, 2012. 